$\begin{array}{ccc} & \\ & \text { International Journal of Social Research } \\ \text { Social Research } \\ \text { (ISSN:2576-5531) }\end{array}$

\title{
Modernization strategies and agricultural development in Senegal: A model for policy analysis
}

\author{
Amadou NDIAYE ${ }^{1}$, Keith M. MOORE ${ }^{2}$ \\ ${ }^{1}$ UFR S2ATA, Université Gaston Berger, Saint Louis, Senegal; \\ ${ }^{2}$ OIRED/Virginia Tech, Blacksburg, Virginia, USA
}

\begin{abstract}
Since independence in Senegal, the agricultural sector has been *Correspondence to Author: considered the vanguard of development. With this intention, Amadou NDIAYE sector development strategies at a cost of billion dollars have UFR S2ATA, Université Gaston been formulated around technical, economic and social axes. Berger, Saint Louis, Senegal; The technical axis consisted of introducing agricultural equipment and infrastructure, rebuilding the seed bank, and improving hydraulic management. The economic axis involved developing a formal credit system and new marketing systems. The social axis stressed new production units and professional associations. The results of these strategies of intensification, improved profitability, and producer organization remain limited and Senegalese agriculture continues to experience cyclical crises. Why don't these strategies of modernization achieve the expected results? What strategy is needed to modernize and develop agriculture in Africa, and particularly in Senegal? To answer these questions, we introduce an analytic framework based on a study of over 50 years of Senegalese agricultural policy and practice (Ndiaye, 2013). This framework provides new policy insights by more clearly distinguishing between development strategy comHow to cite this article:

Amadou NDIAYE, Keith M. MOORE.Modernization strategies and agricultural development in Senegal: A model for policy analysis. International Journal of Social Research, 2020; 4:45. ponents, actors and consequences.

\section{eScî̀Pub}

eSciPub LLC, Houston, TX USA.
\end{abstract}

Keywords: agricultural education, subsidies, producer organizations, intensification, profitability 


\section{Introduction}

Since independence in Senegal, the agricultural sector has been considered the vanguard of development. With this intention, sector development strategies at a cost of billion dollars have been formulated around technical, economic and social axes. The technical axis consisted of introducing agricultural equipment and infrastructure, rebuilding the seed bank, and improving hydraulic management. The economic axis involved developing a formal credit system and new marketing systems. The social axis stressed new production units and professional associations. We will use the term modernization to include all of these processes involving the transfer of standards of contemporary agricultural practice in developed countries along these three dimensions.

The results of these strategies of intensification, improved profitability, and producer organization remain limited and Senegalese agriculture continues to experience cyclical crises. Why don't these strategies of modernization achieve the expected results? What strategy is needed to modernize and develop agriculture in Africa, and particularly in Senegal? To answer these questions, we introduce an analytic framework based on a study of over 50 years of Senegalese agricultural policy and practice (Ndiaye, 2013). This framework provides new policy insights by more clearly distinguishing between development strategy components, actors and consequences.

Senegal's first agricultural development plan began with great hopes. Starting from 1958, the Socialist government of Senegal launched a fundamental reconsideration of the existing commercial agricultural economy and established agricultural cooperatives whose essential functions were the supply in inputs and agricultural equipment, the collection and marketing of outputs. This first period is characterized by an agricultural economy managed by government economic and technical specialists through the agricultural cooperatives. However, the political crisis in
1962 brought about by dysfunctional cooperatives led to the cooperatives becoming sociopolitical organizations and the State reorienting agricultural policy toward a productivist approach.

Gradually, the decentralized productivist orientation gained the upper hand in the cooperative structures. Decentralized growth was adopted through specialization according to agro-ecological zone. In this way, productivism became the dominate policy orientation, but it was complemented by programs to eliminate illiteracy, small transformation and packaging activities, and targeting women and youth. Despite these major investments, the 1970s ended in a serious crisis for Senegalese agriculture. The drought of the 1970s, the oil crisis of 1973 and lower it prolonged courses of the agricultural raw materials (starting from 1968) are marked moderately to be the main causes of the policies of structural adjustment. These crises led to the establishment of the Economic and Social Recovery Program in collaboration with the IMF. This program set the structural adjustment policies which began in 1979 with the elimination of the productivist agricultural subsidies.

The disengagement of the State from the productive sector, the liberalization of the economy and structural adjustment lasted almost 20 years. In the agricultural sector, these policies led to reduction of personnel and the dismantling of the cooperatives in an attempt to encourage producers to take the initiative. To facilitate this effort, any structure (farm, group, or producers' organization) whether family or not could be constituted in as a business (groupement d'intérêt économique-GIE), without taking account of its specific nature. As a consequence, these policies allowed the development of NGOs and their national platform (the Cadre National de Concertation et de Coopération des Ruraux-CNCR) which validated peasant society. Nevertheless, the implementation of these measures met considerable resistance. 
By the mid-1990s, the re-establishment of macro-economic balances, the devaluation of West and Central African Franc and the policies of privatization allowed for a new policy proclamation which only began to function in 2001. By 2002, a new crisis (a bad crop year) required the government to take new measures. This led the Head of State to initiate a special maize program with the objective of producing 100,000 tons in the same year. Then came the food crisis of 2008 which set the policies back again. A new centralized and productivist policy was implemented involving the Great Agricultural Offensive for Food and the Abundance (GOANA).

Since the 1970s, despite frequent efforts by the Senegalese Government to mobilize the agricultural sector little progress has been made.

During the agricultural season of 2011/2012 farmers experienced eight months of famine before the harvest. The new government had already invested 34 billion CFA francs to support areas at high risk of food insecurity. Peanut ${ }^{A}$ production had fallen by $52 \%$ and cereals by $32 \%$ in the previous year. Again and despite careful preparation by the Government, annual production for 2013/2014 encountered several obstacles. Agricultural operations in the Senegal River Valley, particularly the irrigated area served by outdated hydraulic pumps, experienced significant damage. While peasants complained of the high cost of inputs with a fifty percent increase in the price of urea, floods of irrigated plots and bird attacks devastated more than 100 farm families' fields ${ }^{\mathrm{B}}$.

In rain-fed areas, the Ministère d'agriculture et de l'équipement rural estimated 6 billion CFA francs of unpaid loans in September 2014. Further, the head of State announced the mobilization of 13 billion CFA francs to pay off the debt inherited from the previous two cropping

\footnotetext{
A Dépéche de l'APS du Mercredi 10 septembre, 2014 15:53

$\mathrm{B}$ idem

$\mathrm{C}$ ibidem

${ }^{D}$ According to the interministerial council on the

development of the rice growing (7/31/2012), 332 billion
}

seasons. With this excessive funding strategy, Senegal occupies a leading role among the best countries of the African union for the allocation of at least $10 \%$ of the national budget to the agricultural sectors for the past 6 years. We need to acknowledge that since independence, the State of Senegal has always regarded agriculture as a driving sector in its development and there have been many investments. Paradoxically, projections reported another 600,000 people will be affected by the current drought (2013-2014) and will need assistance ${ }^{\mathrm{C}}$. Basically, Senegalese agriculture crises appear more structural than conjunctural. In addition, we must recognize that agricultural policies in Senegal have not yet provided results in terms of job creation and becoming the engine of development for other sectors. What accounts for the structural nature of this crisis? How can it be broken?

In any case, the current Government still intends to make the agricultural sector the lead sector for the country's development, with forecasts for huge ${ }^{D}$ budgets. With an emphasis on technical modernization, rural mechanization and the reconstitution of the seed bank constitute major axes of intervention. Repeating the emphasis on agricultural mechanization, water control, and technological packages that have been the major themes of research and the agricultural framework for years.

Modernization has been taken into account in the policies and actions of rural development since the beginning of independence. Certainly, the mastery of these elements (intensification, profitability, and producer organization) is an important factor of agricultural development. All countries (for example, France, USA, etc.) that have developed their agricultures have some control over this process. Then why don't

West African Francs are necessary over the period 20122018 to reach rice self-sufficiency. In the Triennial Program of Public Investment (PTIP), not less than 500 billion are planned for only investment in the sector. 
modernization strategies reach successful outcomes in Africa?

At least two observations are necessary. First, modernization driven by the State has allow for some development of infrastructure, equipment, inputs, technology, land, and agricultural markets. Second, these forms of State provision proved effective and efficient in countries like France, Switzerland, etc. where these systems are well integrated, but not in Africa. Consideration of these two factors poses questions about the nature of the integration of these elements as well as the methods of policy intervention. A better understanding of these linkages would help to improve the integration of farm operators and these modernizing resources (infrastructure, equipment, seeds, other inputs, skills, and markets). How can we analyze these interrelationships? Based on this understanding we propose a new approach to analysis, description and evaluation of agricultural policies.

\section{Objectives}

This work aims to introduce a model for the analysis and characterization of agricultural and rural development in order to indicate policy options for the development of agriculture in Senegal and across Africa. We apply the model to:

1. characterize the three agricultural subsystems: production structures, education, and subsidies,

2. determine the strategy of each sub-system, and

3. analyze the interactions between these subsystems and strategies to understand the functioning of various agricultural and rural development systems.

This Agricultural and Rural Development System (ARDS) model was derived from an inductive analysis of Senegalese agricultural development (see Ndiaye, 2013). The approach captures systematic and interactive dynamics as a function of relationships between agricultural production structures, the education subsystem, and agricultural subsidy practices.

\section{Methodology}

Our analysis is based on a review the relevant literature and primary field research using an integrated rather than a sectoral approach. Data collection exercises involved semi-structured interviews (individual and collective) and surveys with agricultural enterprises, producer organizations, and agricultural and rural development service sector at the local and national levels over a period of years and across multiple projects. Basically, this methodology focused on:

- producers, farms and farmers' organizations,

- agricultural education (training, mentoring and extension),

- subsidies and supporting services to modernize production processes (infrastructure, machinery, seeds, other inputs, and markets)

Producers, farms and farmers' organizations

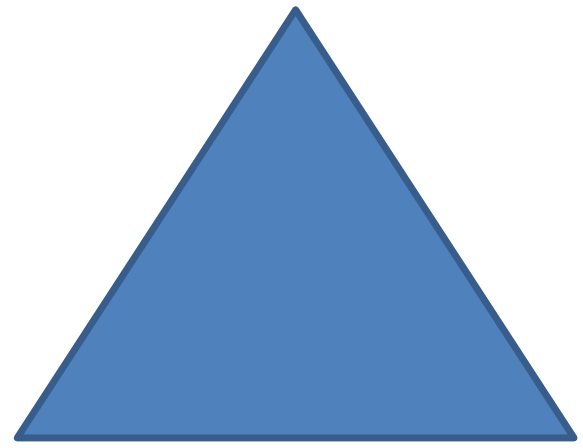

Agricultural Education (KIM, socialization)

Subsidies and supporting services

The application of this model allows us to determine three dominant types of ARDS: peasant, farmer, and industrial.

\section{Analysis}

In order to present the ARDS we will investigate the agricultural context of Senegal in contrast with other country experiences with respect to: (1) production structures; (2) agricultural education; and (3) subsidies. This analysis will also consider the interaction of these subsystems. 


\section{Types of agricultural production structures}

The organizational structures of agricultural producers (new production units and professional associations) constitutes a determining factor in the development of the agricultural sector. They can be used for production, marketing, supply, investment, and defense of interests through professional/interprofessional or civil society organizations. These structures can exist in individual, family, or associative forms arranged into three types for analytic purposes: peasant, farmer, and agroindustrial.

\section{Peasant type}

In the peasant structure, the producer "inherits" his occupation and his farm. S/he does not acquire the knowledge and skills to farm through a system of formal agricultural education. $S /$ he is trained on the job by parents and community.

Consequently, the basic production structure (farm operation) is not managed professionally and does not function like a business. These are "peasant households" whose livelihoods are derived from an array of productive activities. Survival of the household is their "profession" and they have no formal status as a business. There is no business plan. The peasant farm is characterized by the weight of tradition with strategic importance placed on the consumption unit. The combination "land, work, capital and water" is inherited from the past and privileges subsistence farming, while maintaining a diversity of relationships with the commercial economy. Designation of the head of household is done through inheritance. The labor, primarily family, is not paid, although intra-community exchanges or reciprocity may be involved.

The majority of the production structures in Senegal are characterized by a dominant consumption unit and multiple sources of income ${ }^{\mathrm{E}}$. Each source of income should be considered as discrete. The notion of discrete income sources is retained here to translate a reality in which crops or livestock, along with other activities (remittances, commercial activities, workshop per diems, etc.), constitute multiple sources of income for the consumer unit. This characterization does not fit with the current definition of farming in developed countries where the economic functioning of the production unit (crop or livestock) is determinant. Thus, the basic Senegalese agricultural production unit is not a farm in the narrow neoclassical sense of the word. To characterize Senegalese agricultural production structures, the term 'peasant household' is better suited.

The character of peasant farms influences the nature of producer associations. Generally, we can identify three types of producer organization: one designed to promote the commercial interests of farmers (professional organizations), another to extend their farm production into processing (value chain organizations), and the third to defend producer interests politically (civil society organizations). In Senegal, at the local level as well as at the national level, producers' organization actors intermingle and mix. One has as the impression that the broad-based interests of civil society actors are dominating the implementation of agricultural development projects. Consequently, producer interests are being diluted in civil society organization priorities.

\section{Farmer type}

In the farmer type, the producer is first a professional farmer. He does not "inherit" his role as a producer-farmer. The farmers and family workers are all engaged in farm activities through their economic roles. The farm operation is strategically dominated by economic production which is partly or completely integrated into the commercial economy. The combination "land, labor, capital and eventually water" is determined on the basis of the market and agro-ecological constraints. Like any business, access to farmland is mediated by the market even though family members are the most likely purchasers ${ }^{\mathrm{F}}$. 
External economic interventions and the subsidy system integrate farms as well as professional and inter-professional organizations into market relations. Farmer unions are more interested in promoting their economic benefits than in defending civil rights. Consequently, there is a predominance of the professional and interprofessional organizations in agricultural civil society.

The farm business is the production unit. Consumption is organized separately in households dependent on the external generation of cash income of family members. Thus, the farmer concentrates on the profitability of his farm. Diversification is not excluded; it can even be encouraged. Crop diversification, agrotourism and the performances of social services can be explored as economic activities. Family "solidarity" can exist but it does not constitute the base of the production system. For example, agriculture in Western Europe (e.g., France and Switzerland) is largely dominated by this type of family farm. These exploitations of large surfaces can have averages of 45 ha in France ${ }^{G}$.

\section{Agro-industrial type}

In the agro-industrial type, the producer is an agricultural investor. The producer neither inherits his/her profession, nor the farm operation. It doesn't matter whether $s / h e$ is the son/daughter of a peasant or a farmer, nor having agricultural vocational training. The basic structure of production (agribusiness farm) and its annexes and related upstream and downstream activities are managed professionally as part of a business plan indistinguishable from any other type of enterprise. The majority of workers are employees even if they are from the same family. The industrial farm is normally constituted with the legal status of a corporation.

The combination "land, labor, capital and water" is determined by the market. Like any business, it is subject to market transactions. On agroindustrial farms, the key is to ensure a profit for investors. The investor is overwhelmingly concerned with ensuring the profitability of its operations. Large agro-industrial farms of several thousand hectares, may be predominant in Eastern Europe, Latin America and to a lesser extent in North America or in Malaysia, Indonesia and certain countries of Africa ${ }^{\mathrm{H}}$.

Industrial agriculture entrepreneurs are often in employer organizations. Professional and interprofessional associations are not well represented although trade unions are organized within agro-industrial farms.

\section{Types of Agricultural education}

The agricultural education sub-system is composed of training (formal education), extension (non-formal education) and research. Our typology makes it possible to distinguish three modes of agricultural education: the integrated mode, the semi-integrated mode, and the dual mode. These are analyzed for each of the three types: peasant, farmer, and agroindustrial.

\section{Peasant Education}

Peasant agricultural education is founded on a dual mode in which formal training is provided to technicians and extension agents of the state and non-formal training is provided by these extension agents to peasants. The formal system is only responsible for training agricultural technicians who can be employed in extension services. These advisors are charged to train and support the peasants who received only on-the-job training in the field with family members. The formal agricultural education system does not provide curricula for training these producers, nor do peasant farmers receive basic vocational training.

In general, technologies of agricultural modernization are introduced to illiterate peasant-producers by agricultural technicians (veterinary doctor, agronomist, engineer, technical officer) who have scientific training. These technologies are fundamentally alien to the peasant's agricultural frame of reference.

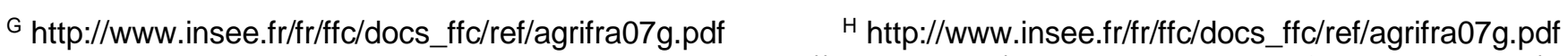
Https://escipub.com/international-journal-of-social-research/ 
The ignorance of these scientific foundations is often the cause of confusion. Extension advisory services tend to work with producer organizations rather than with individual farms. Improving peasant production involves transferring technological packages, as well as management tools and skills developed by national agricultural research to peasant organizations. Further removed, these research activities are conducted in centers independent of extension offices. For example, farmers who refer to the logic of traditional veterinary art, often blend modern products in all ignorance of their incompatibilities. Furthermore, the use of modern technological packages often requires maintenance of equipment that illiterate producers do not understand. There is a fundamental disconnect between the rationality of modern technologies and that of traditional peasant knowledge. The reality in Senegal is that there is no agricultural school whose goal is to train producers. The agricultural education system is built so that diploma graduates are recruited for the bureaucracy. As extension workers, they are responsible for introducing untrained producers to technological packages for which they have not been prepared.

\section{Farmer Education}

In the farmer education type, professionalization of the farmer is the primary objective. The rationality of the producer is accomplished by the formal agricultural education system. Extension and farm management is only a final link in developing modern professional farmers. The same education system trains the agricultural extension workers as well as farmers. In addition, agricultural education and research are closely linked. Thus, agricultural extension activities for farmers are more concentrated on problems specific to individual farms whereas those for peasants focused on general modernization themes. Farmers' formal training is the foundation of modern professional actors.

There are two modes of farmer education, integrated and semi-integrated.
The integrated mode corresponds to a combination research, teaching and extension. Non-formal education and research are integrated with the system of formal education. The basic training of the producers and their technical support are under the responsibility of only one structure. Two cases can be distinguished:

- The case of Land-Grant University in the USA: Farmers' formal professional training begins in high school agricultural classes, and/or in agricultural colleges and universities. Once in the field, non-formal agricultural education (extension) is ensured by the agricultural universities which have departments of agricultural communication, education and extension.

- The case of agricultural centers in Switzerland: Farmers' formal professional training begins either in the cantonal agricultural centers, or in the universities. Once in the field, non-formal agricultural education (extension) is ensured by these same cantonal agricultural centers which maintain a team of advisors.

The semi-integrated mode corresponds to a partial combination research, teaching and extension. The basic vocational training of the farmers and their advisors is done by the system of formal education. But, on the ground, nonformal education (extension) is conducted by a structure independent of the education system. In the case of France, research is conducted in separate institutes of research and later transferred to the public agricultural extension which is ensured by the Chamber of Agriculture (technical advisors) and the Center for Rural Economy (management advisors). The agricultural advisers are trained, like the producers in the system of formal education (agricultural high school and universities).

\section{Industrial Education}

In general, agricultural education is not involved in the training of agricultural investors. However, investors can profit from management training and recruit highly trained technical specialists to 
populate the productive apparatus. Indeed, basic agronomy is no longer taught in the USA it has been divided into several specializations: soils, plant protection, biotechnology, etc. These specialists enable them to create powerful units of research and development inside the agroindustrial company. Relations with public extension and advisory services are exceptional. The agro-industries have internal mechanisms for training and human resources development. A genuine policy of training and building capacity of agents is developed, even if its application requires the use of experts outside the enterprise.

\section{Types of Agricultural Subsidies}

Agricultural subsidies are accepted and practiced world-wide. Two modalities of subsidy can be identified: direct subsidies to farmers and indirect subsidies through intermediaries in the market. These modalities are analyzed for each of the three types: peasant, farmer, and agroindustrial.

\section{Peasant subsidies}

Peasant subsidies are dominated by an external power (public, para-public and NGO) that provides targeted funding for specific inputs and innovations without regard to the needs of each peasant household. Rather, they are designed to directly support the perceived needs of the State's modernization project. This is case in Senegal where modernization is centered on fertilizers, pesticides, machinery, infrastructure, and technological packages. The State subsidizes these inputs through intermediaries in the market. In the process profits are captured by input operators rather than invested in the development of peasant farms.

\section{Farmer subsidies}

Farmer subsidies, as in France or the United States, are a matter of a partnership with the State. The need for modernization and intensification of production has been internalized by the farmer in his/her business plan. Consequently, subsidies are made by the State directly to the farmer. Farmer subsidies are framed by state policy. However, inputs and equipment are not purchased for distribution to farmers; each farmer is responsible for acquisition and maintenance of his/her machinery, infrastructure and inputs.

Farmer subsidies are designed to maintain transparent management. It leaves entrepreneurs free to manage their operations according their business plans. The State sets up a certain number of criteria (technological innovation, crop selection, acreage, management of natural resources, etc.) that put the development of the farm enterprise at the center of the process. The State, through direct transfers or allowances with the bank credit, can subsidize the farm which, itself, sets the wheels of production in motion, buying farm equipment, seeds and other inputs. Each farm uses State subsidies for the implementation of its business plan. In Switzerland, for example, these subsidies are distributed according to preset criteria (minimum surface, selected crops, quantity produced, productivity, environmental measurements, conformance with other State policies, etc).

\section{Agro-industrial subsidies}

Agro-industrial investors are basically interested in the business environment (credits, taxation, exemption, competition, market, import-export, etc.) favorable to the profitability of their investments. The key is to guarantee the market for these investors. In the USA for example, the fact that the State provides food subsidies for citizens (through a distribution of food stamps) contributes to this guarantee. The purchase of produce to constitute food stocks for PL480 plays the same role. If the State guarantees the environment of business and contributes to the guarantee of the market, the producing investor is only concerned with combining the factors of production (financial and economic, human, material and technological) in an optimum way to ensure corporate revenues. Application of ARDS to Senegal: the interaction of the subsystems 
Since the 1960s, agricultural development policies have been based on the modernization of agricultural production. These policies are interdependent involving (1) the introduction of modern technologies (through indirect grants and support); and (2) the non-formal education of peasants (through agricultural extension advisory services). But, the 'introduction of modern technologies' which mobilizes billions dominates these interrelationships. This approach focuses on sectoral productivity enhancement rather than on overall system functioning. As such, this approach involves the introduction of modern machines, fertilizers, seeds, plant protection products, infrastructure, etc. It does not take into account either actors (producers) or the nature of their production units. All producers and all production units are treated in the same way by the modernization approach. There is no analysis to identify differences in order to propose alternative approaches.

The majority of farm structures in Senegal are not managed professionally and do not operate as businesses. These structures are characterized by the centrality of the consumption unit. In addition, there is a multitude of producer organizations that are more representative of civil society than vocational interests. The lack of professionalization of peasants, the centrality of the consumption unit, and the dominance of civil society organizations are determined by the agricultural education and the agricultural subsidies sub-systems.

Agricultural education in Senegal is centered on the training of technicians to become employees of the public administration. Consequently, these state employees become the defacto managers of agricultural production despite their lack of direct integration with production units. On the other hand, there is no formal vocational education for producers. The latter, must settle for the activities of capacity building and training sessions offered by the agricultural extension service or NGOs. These extension service activities work more with civil society organizations than with peasant structures.

Agricultural subsidies are not centered on the needs of farms but on assumed sectoral modernization. These subsidies create an overabundance of rural organizations who are neither vocational groups, nor trade-union organizations in defense of peasant interests. They simply reflect economic niches and political positioning. Overwhelmed by the multiplicity of production units to manage, extension agents prefer to operate through these agricultural or community civil society organizations.

This example of sub-system interaction characterizes the Peasant ARDS in Senegal. The systemic approach allows us to understand why sectoral policies of agricultural modernization and professionalization were not able to attain their objectives. Agricultural development policies in Senegal failed to recognize that the farm operators in the Peasant ARDS do not have the same vocational characteristics as those in developed countries. In fact, the stability of peasant structures depends on the failure of agricultural education and subsidy sub-systems to directly address the reality of their circumstances.

In order to professionalize the producer, it is necessary to act through formal agricultural education and production unit subsidies. In countries where the producer (farmer or agroindustrial) are professionals, the mode of agricultural education and the modality of subsidies are different than those found in Peasant ARDS (as in Senegal). The Farmer ARDS and the Agro-industrial ARDS rely on subsidies flowing to the primary producing units and farm personnel are formally trained through the educational sub-system.

\section{Comparison with other ARDS}

Across the world, one observes agricultural producers who seek to assure the continued profitability of their production activities. They seek a return on their investment. They diversify and intensify their activity with the acquisition of new technologies. This is the case of farmer and Https://escipub.com/international-journal-of-social-research/ 9 
agro-industrial production structures. In association with diverse modes of agricultural education and modalities of agricultural subsidies the two other predominant ARDS (Farmer or Agro-industrial) are created.

In the Farm ARDS, professionalism is central. The agricultural workforce is composed of clearly identified roles: owners, salaried employees, cooperatives, agricultural advisers, teachers, trainers, researchers, regulators. Each actor works as professional which enables $\mathrm{him} / \mathrm{her}$ to earn a living. Participation in cooperatives and other farmer organizations is an extension of the economic functioning of the farm, on the one hand, and developing political support for farm policies, on the other. In Switzerland, this professionalization was constructed through an integrated mode of agricultural education, the Cantonal Agricultural Centers and maintained through the modality of direct subsidies to farmers. In France, professionalization is assured by basic training in agricultural high schools and advisory services in the Chambers of Agriculture. These farmers are also maintained through direct subsidies. For example, the French or Swiss governments do not invest directly in farm machinery and inputs but rather offer grants to identifiable tax paying farmers so that each can implement their own business plan.

In the agro-industrial ARDS, professionalism is assured by a high degree of specialization of the workforce within the production unit. Each worker (from field labor to technical experts) is recruited according to a vocational profile established for their position and must maintain and enhance their technical skills. Employee representation is channeled through contracts and where legitimate trade unionism to improve material conditions. There is no vocational education sub-system for agricultural investors. Nevertheless, the investors profit from the vocational training provided by the modes of the existing agricultural education system. Specialization and the division of labor have advanced to the point where education providing the technical expertise of marketing and business management is separated from that for technical agricultural production activities. In addition, there is an internal structure for training and human resource capacity building. Given the differentiated internal structure of agroindustrial enterprises they can benefit from both direct and indirect subsidies.

\section{Conclusion}

Worldwide, it is generally accepted that if the conditions are appropriate, the development of the primary sector should promote the secondary and tertiary sectors. This theory posits that the development of agriculture supplies inputs to the industry which in turn, enables the development of services. It is as well as in African countries, including Senegal, agriculture and rural development has always been regarded as the engine of development for other sectors. Consequently, proactive agricultural policies have been developed and implemented. Regularly renewed since independence, they have generally focused on modernization actions (intensification, profitability, producer organization) targeting the sector as a whole. This modernization is expected to generate agricultural and rural development. It is clear that the results of all of these policies are mixed.

This study particularly questioned the interactions between components and approaches to modernize development of the agricultural sector. The combination of the units of production, subsidies and policies, and agricultural education including their interactions is called the Agriculture and Rural Development system (ARDS). Organization and interaction of the three elements determine the self-regulation of the whole system. The ARDS can be considered a model of systemic analysis and characterization of a country's agricultural development system helping us to understand subsystem interactions. The ARDS approach provides new insights on the interrelationships between sub-systems allowing for an improved understanding of the pathways and dead ends in 
the generation of a modern agricultural system. Thus, the structures of production (farm), subsidized inputs (grants) and professional (agricultural education) and their interactions characterizing the processes of agricultural and rural development.

The application of this model of analysis identified three theoretical types of ARDS: the peasant system, the farm system and the agroindustrial system. Each system determines the production structures and procedures for upgrading machinery and professionalization. Taking into account the relationship between the three elements of the system, one can distinguish sectorial development policies from integrated agricultural development policies.

Thus, the success of the policies of modernization strongly depends on the system in place as well as the approach of integration implemented. To the extent that policy interventions are independent of one another, we can qualify it as a sectorial approach and to the extent that they are articulated with one another, we can say that the approach is integrated. the Senegalese experience suggests that it is difficult to develop agriculture through a sectorial approach based on subsidized modern inputs for the sector as a whole and lacking basic agricultural education for the key actors at the production level. Basically, agricultural policies must take into account, an integrated and systemic approach to vocational training of future agricultural producers who will implement modern agricultural production instead of the prevailing peasant farms in Africa. Any policy and agricultural development strategy should target and articulate the interrelationships between the three sub-systems: (1) the structures of production (farms and organizations); (2) agricultural basic training and extension (modalities of professional modernization); and (3) subsidies and policies (supporting material and institutional improvements). Of course, one can have various degrees of integration. The determination and success of these approaches to agricultural development must take into account the type of existing ARDS.

\section{References}

1. BENOIT-CATIN M., FAYE J., 1982 - L'exploitation agricole familiale en Afrique Soudano-sahélienne, Paris, PUF, 1982.

2. BENOIT-CATTIN M. 1986 - Les Unités expérimentales du Sénégal, ISRA - CIRAD FAC, 1986, $477 \mathrm{p}$.

3. BERTI F. et LEBAILLY P. - L'agriculture familiale africaine au cœur des Objectifs du Millénaire pour le Développement (OMD); Unité d'Economie et Développement rural Gembloux Agro-Bio Tech Université de Liège, $15 p$.

4. BROSSARD J. et al., 1995 - Gestion de l'exploitation agricole familiale : éléments théoriques et méthodologiques, ENESAD CNERTA, 1995, $215 \mathrm{p}$.

5. BROSSIER J., CHIA E., MARSHALL E., PETIT M., 1997 - Gestion de l'exploitation agricole familiale : Eléments théoriques et méthodologiques, Dijon, ENESAD CNERTA, 1997, $217 \mathrm{p}$.

6. CROZIER Michel et FRIEDBERG Erhard, 1992, L'Acteur et le système: Les contraintes de l'Action collective, Paris, Seuil, col. Points-Essais, $500 \mathrm{p}$.

7. DEBOUVERY P. 2007 : la formation de masse face aux enjeux de développement des exploitations familiales rurales ouest-africaines. Communication au séminaire sous régional CIFA/ RESOF/ CIEA : SEN 07., Saint louis, 15pages.

8. DIAO F. D., 2003 - Typologie des exploitations agricoles de la zone cotonnière sénégalaise : affinement du modèle de la SODEFITEX. Mémoire de fin d'études ENSA Thiès Sénégal. Février 2003, $73 p$

9. DUMONT R. , 1962, "I'Afrique noire mal partie", édition seuil, Paris,

10. KANOUTE A., 2003 - Etude comparative des stratégies de couverture de besoins céréaliers dans les exploitations familiales de la zone cotonnière sénégalaise. Mémoire de fin d'études,

11. ENSA Thiès, Février 2003, $53 \mathrm{p}$.

12. NDIAYE A. 2013 : L'agriculture Sénégalaise de 1958 à 2012 : analyse systémique et prospective. L'Harmattan, collection : Etudes Africaines. , 224 p.

13. NDIAYE, A. And M. M. GNING. 2015. "Prise en charge des besoins alimentaires dans l'arrondissement de Notto (Sénégal) : Stratégies des explointations familiales et $d u$ 
gouvernement". In Notes Scientifique: Homme et Société. Editée par la Faculté des Sciences de l'Homme et de la Société, Université de Lomé. No. 3, juin 2015. Pp: 121-135. ISSN: 2409-9791.

14. NDIAYE A. 2016 «Paradigmes $d u$ développement: quels systèmes et approches pour l'Afrique », Paris, Harmattan, collection: Etudes Africaines. ISBN: 978-2-343-07740-6, 236 pages

15. NDIAYE A. 2018 «Pastoralisme, résilience et développement: Des forages et de la grande muraille verte » Dakar Harmattan, ISBN : 978- 2343- $15253-0,287$ pages

16. NDIAYE A. 2018 «Système d'innovation agricole: Guide stratégique et pratique de conseil agricole », Dakar, Harmattan, ISBN : 978-2-34314501-3, 209 pages

17. NDIAYE M. , 2014 : “Typologie et analyse de la dynamique des exploitations agricoles familiale dans la région de Kaolack", mémoire de Master 2 Développement rural et coopération, UFR SEG, UGB, $70 \mathrm{p}$.

18. REQUIER- DESJARDINS D., 1994 - L' « économie des organisations " et l'analyse $d u$ comportement des unités domestiques en Afrique sub-saharienne, tome XLVI, vol no4, 1994, 105$131 \mathrm{p}$.

19. REQUIER- DESJARDINS D., 2003- « Le capital social dans la théorie économique : actif privé ou bien public ? Le point sur quelques contributions récentes », In, J. Ballet et R. Guillon (éd), Regards croisés sur le Capital Social, 2003, pp : 19-39.

20. REDFIELD R., 1956, Peasant society and culture. Ithaca, Cornell University Press.

21. SAKHO-JIMBIRA M. S., 2004 - De l'exploitation agricole familiale au système d'activités: une étude de cas du bassin arachidier du Sénégal. Mémoire de D.E.A, Ecole Nationale Supérieure Agronomique de Montpellier. Septembre 2004,87p.

22. SAKHO-JIMBIRA M. S., BIGNEBAT C., SOUBEYRAN R., CATTIN M. B., 2008- Les ressorts internes de l'autonomie alimentaire des groupes familiaux du Bassin arachidier Sénégalais, INRA SFER CIRAD, décembre 2008 - LILLE, France, 24p.

23. SARR D., THIAM A. et GARIN P., 1987 Description d'une Typologie de Structure des

24. Exploitations dans la communauté rurale de Kaymor (Sud région de Kaolack). ISRA, Mai 1987, $18 \mathrm{p}$.

25. TCHAYANOV A., 1972 - Pour une théorie des systèmes économiques non capitalistes. - Revue Analyse et Prévision, tome XIII, 1972, 19-51 p.
26. http://www.fao.org/farmingsystems/description_fr .htm

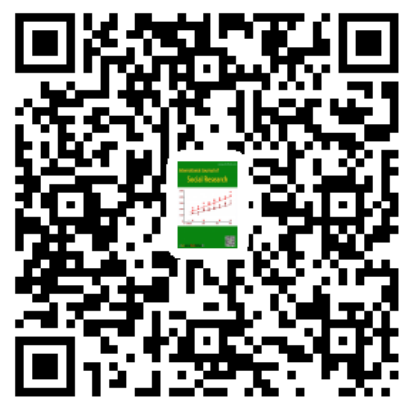

